\title{
Role of the Biological Processes in Soilforming Process and Soil Fertility (Azerbaijan, Shamakhy)
}

\author{
Bagirova RF* \\ Institute of Soil Science and Agrochemistry NAS, Azerbaijan \\ *Corresponding author: Bagirova RF, Institute of Soil Science and Agrochemistry NAS Azerbaijan
}

Received: 贉July 15, 2019

Published: 眥July 29, 2019

\begin{abstract}
The article discusses the impact of the erosion process on mountain black terrestrial, suitable for planting soils widespread in the Shamakhi region of Azerbaijan, which are more or less subject to erosion, which impairs its fertility, weakens fertility etc. It should be recognized that the influence of agricultural activity of man on the processes taking place in the soil is a deeply studied problem. What contributed to the negligence of the soil, its incorrect and irrational use which weaken its fertility, change the normal direction of the process of soil formation. According to the latest data, more than $50 \%$ of the soils of the Shamakhi region are subject to the process of water and irrigation erosion, a process that is widely distributed mainly in mountain black-terrestrial. According to well-known scientists of the republic, it was found that substances synthesized by microorganisms that regulate the complex processes occurring in the soil. For example, the conversion of plant residues and organic substances into humus takes place under the influence of complex environmental factors, which impairs its fertility. This was compared to our study of the dynamics of microbiological activity in black mountain soils and the effect of erosion on it at the object of study. As you know, humus is the basis of soil fertility. For this reason and in the process of research, the factors that form the soil were the focus of genetic science on soil. The results of the study proved that the erosion process, which occurred in nature, possessing a huge potential for its destructive power, destroys the surface fertile soil layer, cancels its fertility and, therefore, removes soil from agricultural circulation. Being a dynamic process, it changes the appearance of a zone, as a rule, a landscape that is widely distributed in the mountainous and foothill zones of the region. This is the reason for the change of the initial relief in the morphological structure and mountain landscapes.
\end{abstract}

Keywords: Soil; Plant; Erosion Landscape; Microbiological Action

\section{Introduction}

An importance of the biological processes, mainly microbiological process is great in a period of the soil science and biology science development, especially in biotechnology science formation (Figure 1). The significance for the microbiological process in the xx century is explained that an intensity of the processes in our environment, biosphere is closely connected with microorganisms activity. Synthesis and resynthesizes of organic substance, humus mineralization and humification processes in soils are performed by microorganisms. Microbiological process is great in decomposition of the nutrient total forms, in provision of soils with the nutrient. It is already determined that the substances which are synthesized by microorganisms regulate the complex process occurring in the soil $[1,2]$. Turning of the plant residues and coarse organic substances into humus mainly occurs under an influence of the complex ecological factors and forms a basis of the soil fertility.

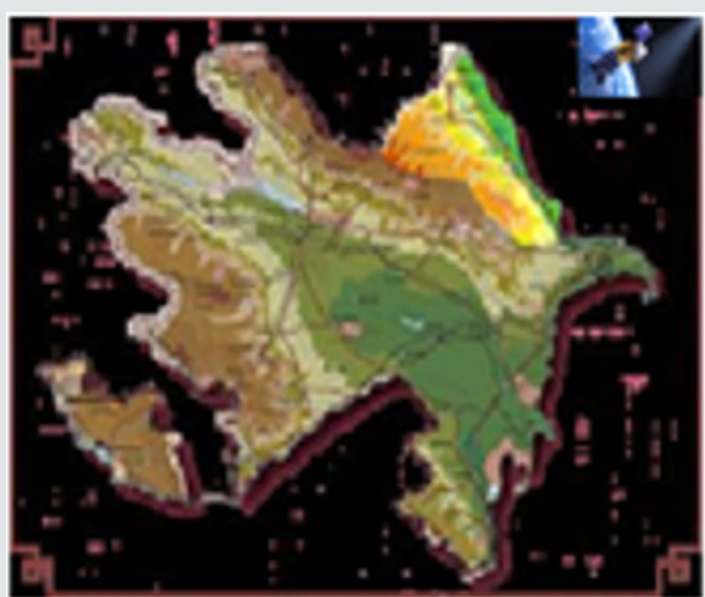

Figure 1: Biological Processes. 


\section{The Course of the Study}

The microorganisms decompose organic substances in the soil, turn the nutrient in their composition to a form which can be appropriated for the plant, create a favourable conditions for their nourishment. The microorganisms also perform sanitary work, prevent from contamination of the environment, especially, soil. As it is not noted that there is a great role of the microorganisms in soil fertility formation. They carry on the organic substance decomposition till the whole mineralization. The plants synthesize the organic matter, the animals fulfil its mechanical and biochemical decomposition and prepare for humus formation in future. But the microorganisms finish the substance decomposition, synthesize the soil humus, and decompose it again when unfavorable conditions are created. B.G. Shakuri commented that all the organic wastes are turned into the inorganic substance form because of the microorganisms' activity. Without participation of microorganisms exposing of the organic matters to such change and their appropriation by the plants are impossible [3]. Besides it, they cause substances circulation in the nature, soil fertility, oil and pit coal formation, mountain rocks weathering and formation of the other natural phenomena. If there are not rottenness microbes, the plant and animal remnants gather on the earth and it can`t be possible to move. It was always defined that an intensity of the biochemical processes occurring in the soil depends on physical, chemical indices, environment development phase of plants, temperature, humidity and other factors of the soil. Just therefore, as a result of the presented factors change, an activity of ferments in soil alters. In this connection an importance of the soil microflora is great in assimilation of the the soils, exposed to the anthropogenic pressure and degraded.

This is also connected with intensive use of soils. Management of the soil fertility requires an investigation and regulation of their biological activity. In this connection some groups of the researchers gave the detailed information about the soil roofing, biochemical processes, physic-chemical characters, anthropogenic soils genesis held on the international congresses in the Turkey republic in 1998 and "Anthropogenic soil forming problem" held in Moscow in 1997 [4-7]. We should note that only physio-chemical methods aren`t enough in investigation and analysis of soils. The soil scientists already consider that the research of the biological processes is a great problem in assimilation of the soils genetic characters, clarity of their fertility peculiarities and definition of the processes direction. Such an opinion is already formed that a closely relation available between the plant-soil and microorganisms was investigated for the purpose of soil fertility research. Because of more humus in the mountain-black soils an activity of microorganisms is quick. Since before the xx century a role of microorganisms was exactly investigated in creation of the complex processes, including bio-chemical processes, especially humus formation, turning of the atmospheric nitrogen to the biological nitrogen. In connection with this problem Z.H.Aliyev., M.P. Babayev, P.A.Kostichev, Vinogradsky, Shakur B.Q. and others expressed opinions $[3,4,7,8]$. The authors show that the microorganisms role is fixing in decomposition of the plant residues, dead organic world and coarse molecular organic substances and initial humus formation. As is known the all groups in soil microorganisms are available and the separate groups possess a special function. The enough information was given about a participation of the same groups in humus forming process.

A role of microorganisms in soil forming process and humus synthesis was studied by the Azerbaijan scientists. It was determined that the microbiological activity rises while a height of the zone increases till a definite level.

The number and activity of microorganisms aren't at the same Level, they depend on hydrothermal regime, fertility, structure, plant cover, climate characters, humus supply, nutrient quantity and so on. All the sorts (surface, linear, irrigation, pasture and wind erosion) of erosion in the region having a complex geological and geomorphological structure develop and consequently the soils fertility is disturbed, fruitfulness ability gets reduced. More parts of the agricultural areas good for sowing deteriorated, but one part was withdrawn from crop rotation. Here the rivers and other water sources became turbid, provision of the local hydrological regime and areas with humidity deteriorated [9]. The greatest part of the Shamakhy region in which the first farming culture develops is situated in the upland zone. Since very ancient periods the relief condition complexity in the mountain zone used in intensive farming and cattle-breeding is characterized by splintering of the firm rocks, unequal distribution of rainfalls on seasons and falling of the rains in a pouring form.

\section{Discussion Materials}

As a result of the joint impact of the anthropogenic and natural factors the soils expose to the erosion process, their upper rotten. Layer are washed out and Lose their fertility. The humus quantity in such soils gets reduced for the first time, its fraction structure detectives, its fraction structure deteriorates, the mobile part of human acids which is agronomically valuable decreases. So, erosion negatively affects the main parameters of the humus forming process in soil. Erosion deteriorates decomposition of $\mathrm{CO}$, its respiration in soil $[8,10]$. The erosion process weakens the microbiological process which is one of the main factors in soil fertility. It should be noted that the soil microflora is a decisive factor of the biochemical processes and regulates the humus synthesis and mineralization. Generally, the erosion process deteriorates physicocharacters, its water regime and food balance. The erosion process reduces water supply of soil, creates arid conditions and this is dangerous for dry- farming land. An evaluation of all the factors (plant, soil, relief, climate and so on) is required for a comparative character of the soil productivity and fertility and this forms a complex valuation method of the soils ago ecological condition. The microbiological processes in eroded and average eroded kinds of the mountainblack and steppe mountain-brown soils were investigated according to the seasons in the Shamakhy region which is situated in the south-eastern part of the Great Caucasus. An activity of bacteria, radiant fungus and microscopic fungus from microorganisms was studied [9]. Study of the microbiological activity in the un eroded mountain-black soils indicated that (Table 1) a total guantity of microorganisms at 0-17 m layer of the same soils is 11704 thousand in on a gram soil, but it is accordingly 9903 and 7283 thousand at 
17-39 and 39-65 cm stratums. Microorganisms gather on the fertile As is shown from the figures of the table, the microbiological activity in the mountain-black soils was more than in comparison with the other soil types. This is explained that the same soils are rich in humus and nutrient. This creates conditions for a development and normal activity of microorganisms. As is seen, an extremal situation limits microorganisms' development. The erosion process weakens all the micron groups' activity. Decrease of humidity negatively affects an activity of microscopic fungus in the same soils. The microbiological activity of the mountain-black soils with a large fertility potential is high very much. The microbiological activity in un eroded and average eroded kinds of the mountain-black soils was investigated according to the seasons and the obtained results are presented on (Table 2).

Table 1: Activity of microorganisms in the mountain-soils and erosion process impact. ( thousand \% in $1 \mathrm{~g}$ soil).

\begin{tabular}{|c|c|c|c|c|c|c|}
\hline Section № & $\begin{array}{l}\text { Eroded } \\
\text { Degree }\end{array}$ & Deathcamp & $\begin{array}{c}\text { Total Quantity of Micro- } \\
\text { Organisms }\end{array}$ & Bacteria & Radiant Fungus & $\begin{array}{l}\text { Microscopic } \\
\text { Fungus }\end{array}$ \\
\hline 1 & Eroded & $\begin{array}{c}0-17 \\
17-39 \\
39-65\end{array}$ & $\begin{array}{c}11704 \\
9903 \\
7283\end{array}$ & $\begin{array}{l}\frac{9116}{7,9} \\
\frac{8140}{8,2} \\
\frac{6254}{8,9}\end{array}$ & $\begin{array}{l}\frac{2502}{\mathbb{R}, 4} \\
\frac{1585}{1,0} \\
\frac{880}{B, 4}\end{array}$ & $\begin{array}{l}\frac{8}{0,7} \\
\frac{8}{0,8} \\
\frac{8}{0,7}\end{array}$ \\
\hline 2 & $\begin{array}{l}\text { Eroded to an average } \\
\text { degree }\end{array}$ & $\begin{array}{c}0-15 \\
15-38 \\
39-48\end{array}$ & $\begin{array}{l}8635 \\
6361 \\
4951\end{array}$ & $\begin{array}{l}\frac{7004}{8,1} \\
\frac{5194}{8,7} \\
\frac{3986}{8,5}\end{array}$ & $\begin{array}{l}\frac{1554}{8,0} \\
\frac{1102}{7,3} \\
\frac{922}{8,6}\end{array}$ & $\begin{array}{l}\frac{7}{0,9} \\
\frac{6}{1,0} \\
\frac{\mathbf{3}}{0,9}\end{array}$ \\
\hline
\end{tabular}

Table 2: Dynamics of the microbiological activity in the mountain-black soils and an impact of the erosion process on it (thousand at $1 \mathrm{~g}$ soil).

\begin{tabular}{|c|c|c|c|c|c|c|c|c|c|c|c|c|c|c|}
\hline \multirow[b]{2}{*}{$\begin{array}{c}\text { Sect } \\
\text { ion } \\
\text { № }\end{array}$} & \multirow[b]{2}{*}{$\begin{array}{l}\text { Eroded } \\
\text { degree }\end{array}$} & \multirow[b]{2}{*}{$\begin{array}{c}\text { Depth } \\
\text { cm }\end{array}$} & \multicolumn{12}{|c|}{ Seasons } \\
\hline & & & $\begin{array}{c}\text { Total } \\
\text { quantity } \\
\text { of micro- } \\
\text { organisms }\end{array}$ & $\begin{array}{l}\text { bact } \\
\text { eria }\end{array}$ & $\begin{array}{l}\text { Radiant } \\
\text { fungus }\end{array}$ & $\begin{array}{c}\text { Micros } \\
\text { copic } \\
\text { fungus }\end{array}$ & $\begin{array}{c}\text { Total } \\
\text { quantity } \\
\text { of micro- } \\
\text { organisms }\end{array}$ & $\begin{array}{c}\text { bacte } \\
\text { ria }\end{array}$ & $\begin{array}{l}\text { Radiant } \\
\text { fungus }\end{array}$ & $\begin{array}{c}\text { Micros } \\
\text { copic } \\
\text { fungus }\end{array}$ & $\begin{array}{c}\text { Total } \\
\text { quantity } \\
\text { of micro- } \\
\text { organisms }\end{array}$ & $\begin{array}{l}\text { bacte } \\
\text { ria }\end{array}$ & $\begin{array}{l}\text { Radiant } \\
\text { fungus }\end{array}$ & $\begin{array}{c}\text { Microsc } \\
\text { opic } \\
\text { fungus }\end{array}$ \\
\hline \multicolumn{15}{|c|}{2015} \\
\hline \multirow{3}{*}{1} & \multirow{3}{*}{ eroded } & $0-10$ & 14020 & 11533 & 2396 & 91 & 11418 & 8274 & 3066 & 78 & 13141 & 10409 & 2650 & 89 \\
\hline & & $0-20$ & 10962 & 9335 & 1544 & 83 & 8562 & 6321 & 2174 & 67 & 10321 & 8363 & 1876 & 82 \\
\hline & & $0-30$ & 8460 & 7430 & 974 & 56 & 6504 & 4918 & 1544 & 42 & 7949 & 6677 & 1219 & 53 \\
\hline \multirow{3}{*}{2} & \multirow{3}{*}{$\begin{array}{l}\text { average } \\
\text { eroded }\end{array}$} & $0-10$ & 20722 & 9116 & 1526 & 80 & 7608 & 5565 & 1974 & 69 & 8749 & 7081 & 1625 & 78 \\
\hline & & $0-20$ & 8685 & 7537 & 2082 & 66 & 5665 & 4028 & 1637 & 61 & 6479 & 5300 & 1113 & 66 \\
\hline & & $0-30$ & 6506 & 5628 & 835 & 43 & 4601 & 3633 & 933 & 35 & 5004 & 4017 & 942 & 45 \\
\hline \multicolumn{15}{|c|}{2016} \\
\hline \multirow{3}{*}{1} & \multirow{3}{*}{ eroded } & $0-10$ & 14666 & 12096 & 2478 & 92 & 12006 & 8639 & 3286 & 81 & 13467 & 20632 & 2745 & 90 \\
\hline & & $0-20$ & 12169 & 10409 & 1675 & 85 & 8958 & 6572 & 2311 & 75 & 10503 & 8438 & 1982 & 3 \\
\hline & & $0-30$ & 9356 & 8218 & 1081 & 57 & 7066 & 5350 & 1669 & 47 & 8145 & 6827 & 1263 & 55 \\
\hline \multirow{3}{*}{2} & \multirow{3}{*}{$\begin{array}{l}\text { average } \\
\text { eroded }\end{array}$} & $0-10$ & 12661 & 10857 & 1722 & 82 & 7971 & 5703 & 2194 & 74 & 9117 & 7261 & 1775 & 81 \\
\hline & & $0-20$ & 10064 & 8639 & 1357 & 68 & 6190 & 4367 & 1760 & 63 & 6820 & 5618 & 1134 & 68 \\
\hline & & $0-30$ & 7920 & 6998 & 877 & 45 & 4745 & 3724 & 984 & 37 & 5215 & 4208 & 960 & 47 \\
\hline
\end{tabular}

\section{Conclusion and Proposals}

a. Importance of the microbiological process which was paid attention in the xx century is that an intensity of the processes occurring in our environment, biosphere is connected with the microorganism's activity. The organic substance synthesis, rot mineralization and humification processes are performed by microorganisms. A role of the microbiological processes is great in decomposition of the total forms in the nutrient, provision of soils with the nutrient.

b. The erosion process weakened the food potential in the mountain-black and steppe soils, deteriorating the soil fertility parameters limited its fruitfulness ability. The fertility parameters were higher in the mountain-black soils. The mountain-black soils were provided with the nutrient well. 
c. Because of the favorable structure in the mountain-black soils, the soil composition is rich in organic matter. The agrotechical measures consist of performing the tillage and all the cultivation works against the winds direction and slopes diametrically and preserving in moist and so on.

\section{References}

1. Omer Akbu Dahab Human (1997) İnuced change the development of soil and mapping and classification in the Cira agricultural scheme. pp. 243-248.

2. Shakuri BK (2002) Soil biological productivity of the vertical zonality systems in the great Caucasus slope. Real factors in stabilization if the ecological balance, pp. 200-233.

3. Tuay Kizıloglu Serbar Hizamettin Ataoglu (1998) Effecr of microbial inoculation and chemical. Fertiliser of protein, Carlo 2 hydrate and s 2 Oat / ROOt DRY Materr Ratio of Com (Zea mayst) plant. İnternational Simposium on arid region uncoil maneen, pp. 236-242.
4. Babayev MP (1967) Soils and gualitative character of land in the foothill plain of Garabagh steppe. Synopsis of thesis can disappear Baku, p. 1-30.

5. Fobala Castro, Tereza, paz Gonzblez (1997) Antonio Composition and classification of an umbrisot improved for aqriculture. pp. 242-245.

6. Garolaga Shloka (1997) Classification and maping of antropoginic soils in Slovakia Rratslava, Slovac. Respublication, pp. 240-242.

7. Oguz Can Turgay, Koray Haktanur (1998) Investiquation of soil mikrobial. Biomass in the Ankara University, fakulti of agriculture, Kenan Evren Research and framing station soils. International simposium anarial redion soil. Menomena İzmir Turkey, p. 243-248.

8. ZH (2004) Ways to Effectively Use and Preserve Land in MountainFarming Areas of Azerbaijan. Pp. 106-111.

9. Bagirova RF (2000) Impact of the erosion process on mountain-brown steppe soils fertility in the south-eastern slope from the great Caucasus. Materials on study of soil erosion, irrigation and guarding in Azerbaijan, pp. 408-413.

10. Skuing GG (1967) Ensymes in soil. Soil biochem, pp. 241-249.

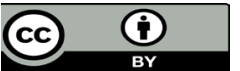

This work is licensed under Creative Commons Attribution 4.0 License

To Submit Your Article Click Here: Submit Article

DOI: $10.32474 /$ CIACR.2019.07.000259

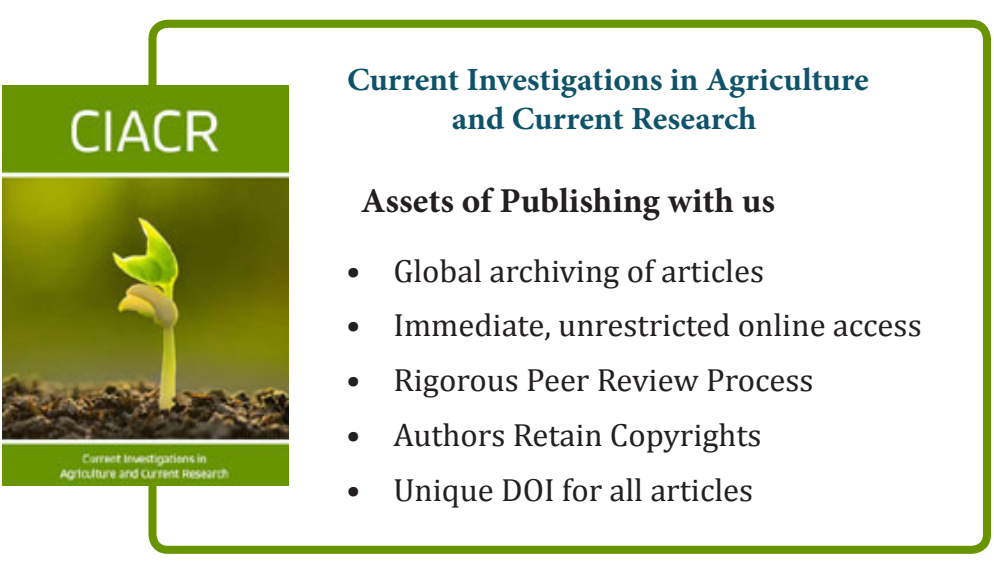

